\title{
AOR
}

Selected Papers of \#AolR2020:

The 22nd Annual Conference of the

Association of Internet Researchers

Virtual Event / 13-16 Oct 2021

\section{TRACES OF BLACK FREEDOM IN THE MACHINE: ETHNOGRAPHIC APPROACHES TO THE STUDY OF DIGITAL BLACK RELIGION}

\author{
Erika Gault \\ University of Arizona
}

\section{Final Abstract}

There was a time when one wanted to learn about Black religion you went to church, the Black Church to be more specific. The "all-in-one agency" which W.E. B. DuBois described the Black Church as certainly operated as a centralized and essential aspect of Black life. Its networks have come to signify Black believers' emancipatory visions since its beginning during slavery in America. Today Black users' contemporary engagement with digital technology has both broadened and complicated the scholarly understanding of the Black Church and Black religion to include more than its Christian manifestation. A number of works (c.f. Brock 2012; Florini 2013; Noble 2018; Watkins 2018) provide important theoretical and methodological approaches to the study of black digital use, digital structures of inequality, and counter-discourse production. On the topic of digital religion, works (c.f. Campbell 2012; Mia Lovheim 2013; Hoover, Echchaibi 2012) have emphasized the importance of digital technology in mediating religious experience. Yet, despite findings that people of African descent are often early adopters of technology, at the intersections of blackness, religion, and digital technology scholarly work remains sparse. This paper provides both a survey and framework for the study of digital Black religion.

This paper takes up works regarding Black religion and media technology (Frederick 2009, Walton 2009, Lomax 2019) as a way of discussing persistent themes and strategies for freedom nascent in Black media making. The digital scene carries many of these same traces in the social media practices of Black religious practitioners. The work of Black religious media scholars is paired with that of Heidi Campbell and others writing on digital religion to offer a needed approach to the articulation and study of digital Black religion.

I also write with a particular regard for how young Black religious bodies have received far less attention in Digital Religious Studies or Internet Studies. Several works have 
taken up religion in digital spaces, the use of ethnography in the study of digital religions, and the mediatization of religion (to name only a few concerns). However, a white lens is usually employed, a critical race/Black theory is absent, or racial homogeneity among research participants is assumed. Without question, when scholars of Black religion write about Black digital-religious life, they have often turned to such theoretical frameworks. New methods for the study of the particularities of Black digitalreligious life are needed. This paper moves in that direction.

First, I examine a few important turns thus far in the study of digital religion and situate Black religious expression in this discussion as an influential framework in establishing religious meaning making online. Earlier works have mostly overlooked the significance of Black programmers, online curators, and content creators in reconstructing the notion of American religion in the last thirty years. Charting the influence of Black religion in the digital not only speaks to the essentiality of its study. But, as the title of this paper suggest, it points to important approaches to the way the digital in religion is explored and the way blackness and Black people in digital spaces are both studied and develop their own epistemologies.

Next, taking a cue from John L. Jackson's "Ethnography Is, Ethnography Ain't" I will briefly introduce "artifacts" from my own fieldwork in order to provide the "kind of writing [and analysis] .... the digitalization of culture demand[s] and afford[s]." Through this process we view the non-linearity, the trans-historical composition of the digital Black Church in its quest for freedom in digital spaces. This points to new theoretical and methodological approaches for the study of the same. Heidi Campbell's theory of networked religion bodes well in this endeavor.

This paper provides a needed next step in the discussion on what the Black Church is and is becoming through the use of digital technology and useful ethnographic techniques for the study of this digital-religious context.

\section{References}

Campbell, Heidi. 2010. When Religion Meets New Media. 1st ed. Media, Religion and Culture. Abingdon, Oxon; New York, NY: Routledge.

. 2012a. Digital Religion: Understanding Religious Practice in New Media Worlds.

New York: Routledge.

2012b. "Understanding the Relationship between Religion Online and Offline in

a Networked Society." Journal of the American Academy of Religion 80 (1): 64-

93. https://doi.org/10.1093/jaarel//fr074.

Jackson Jr., J.L. (2012), Ethnography Is, Ethnography Ain't. Cultural Anthropology, 27: 
480- 497. https://doi.org/10.1111/j.1548-1360.2012.01155Jr,

—. 2013. Thin Description. Boston: Harvard University Press.

Stewart Hoover and Nabil Echchaibi, "The Third Spaces of Digital Religion," working paper, Center for Media, Religion and Culture, University of Colorado, Boulder, Colorado, 2014, https://www.colorado.edu.

Lomax, Tamura. 2018. Jezebel Unhinged: Loosing the Black Female Body in Religion and Culture. Durham: Duke University Press.

Loveheim, Mia. 2012. "Identity" in Digital Religion: Understanding Religious Practice in New Media Worlds edited by Heidi Campbell, 41-56. New York: Routledge.

Walton, Jonathan. 2009. Watch This! The Ethics and Aesthetics of Black Televangelism. New York: New York University Press. 